\title{
Employment protection and globalisation in dynamic oligopoly
}

\author{
Gerda Dewit \\ National University of \\ Ireland Maynooth
}

\author{
Dermot Leahy \\ University College Dublin
}

Catia Montagna

University of Dundee

January 2003

\begin{abstract}
We construct a model in which oligopolistic firms decide where to locate. Firms choose to locate either in a country where employment protection implies costly output adjustments or in one without adjustment costs. Using a two-period three-stage game with uncertainty it is demonstrated that location is influenced by both flexibility and strategic concerns. We show that the strategic effects under Cournot work towards domestic anchorage in the country with adjustment costs while those under Bertrand do not. Strategic agglomeration can occur in the inflexible country under Cournot and even under Bertrand provided uncertainty and foreign direct investment costs are low.
\end{abstract}

Keywords: Uncertainty, Flexibility, Oligopoly, Employment Protection, Foreign Direct Investment, Location.

JEL Codes: D80, F23, L13

Approximate Word Count (including tables, figures and references): 7850

Acknowledgements: We are grateful to David Collie, Peter Neary, Donal O'Neill, Olive Sweetman, participants of the European Trade Study Group (Brussels, September 2001), participants of the Irish Economic Association Conference (April 2002), participants of the European Economic Association Conference (August 2002), seminar participants at University College Dublin, at the National University of Ireland Maynooth and at the University of Ghent.

Correspondence: Gerda Dewit, National University of Ireland Maynooth, Department of Economics, Maynooth, Ireland, tel.: (+)353-1-7083776, fax: (+)353-1-7083934, Email: Gerda.Dewit@may.ie; Dermot Leahy, University College Dublin, Department of Economics, Belfield, Dublin 4, Ireland, tel.: (+)353-1-7168551, fax: (+)353-12830068, E-mail: Dermot.M.Leahy@ucd.ie; Catia Montagna, University of Dundee, Department of Economic Studies, 3 Perth Road, Dundee DD1 4HN, United Kingdom, tel.: (+)44-1382-344845, fax: (+)44-1382-344691, E-mail: C.Montagna@dundee.ac.uk . 


\section{Introduction}

This paper contributes to the understanding of the complex interface between globalisation and labour standards by focussing on the effects of employment protection on the international location of economic activity.

The past decade has witnessed a remarkable acceleration of the process of integration of the world economy - often referred to as 'globalisation'. The liberalisation of foreign direct investment (FDI) policies worldwide, which has resulted in investment flows between countries growing much faster than trade flows, has led to an increase in the ease with which firms (and jobs) move across national borders. As a result, governments' rhetoric and policies increasingly betray concerns about their countries' ability to prevent domestic industry from relocating abroad and to attract and/or retain foreign investment.

Labour market institutions are commonly regarded as playing a crucial role in determining the location of economic activity, not least if they influence the flexibility with which firms can adjust output scale and employment levels to evolving economic conditions. Employment protection laws in particular are identified as a major source of inflexibility and, increasingly, recommendations are put forward that the statemandated redundancy payments - which were introduced in many European countries from the late 1950 s to the early 1970 s - are dismantled. The emerging consensus is that by forcing firms to under-produce during economic booms and over-produce when the economy slows down ${ }^{1}$, high hiring and firing costs undermine their ability to adapt to fast changing competitive markets. Not only is employment protection held responsible for the poor employment performance of many European countries (e.g. Lindbeck and Snower, 1988; and Lazear, 1990) but also for hindering countries' ability to hold on to footloose industries. It follows that, in a world where countries perceive themselves as being engaged in fierce competition for economic activity, the substantial differences that exist between economies (even within the European

\footnotetext{
${ }^{1}$ Bentolila and Bertola (1990) argue that firing costs are likely to have reduced employment variation in Europe.
} 
Union) in hiring and firing restrictions ${ }^{2}$ are seen as a source of unfair "competitive advantage' for those locations with lower costs of employment adjustments.

Whilst a substantial amount of work has been carried out to assess the impact of hiring and firing restrictions on employment ${ }^{3}$, to our knowledge (and despite its prominence in policy debates) the flexibility offered to firms by a given location in adjusting to changing economic conditions ${ }^{4}$ has received relatively little attention in the theoretical literature on $\mathrm{FDI}^{5}$. Instead, the study of industry location has tended to focus on market access and local costs of production as the central determinants of a country's ability to attract FDI and retain domestic firms ${ }^{6}$. These factors are of course important. However, by focusing on the relationship between employment protection and the location of industry this paper fills an important gap in the literature. To explore this relationship, we combine ideas from the industrial organisation and the labour literature, and apply these to a set-up in which firms' locations are endogenous.

We argue that, contrary to the conventional wisdom, labour market inflexibility may not necessarily hinder a country's ability to attract and/or retain economic activity. This view finds theoretical support in the theory of industrial organisation that emphasises how commitment (i.e. inflexibility) may be a source of strategic advantage (Tirole, 1988). We shall therefore investigate how region-specific flexibility affects location decisions when firms are oligopolistic and act strategically. In a non-strategic set-up, flexibility only entails advantages for a firm. This is not

\footnotetext{
2 According to Layard, Nickell and Jackman (1991), firing costs have ranged from 0.48 months salary in Denmark to 5.24 in France and even to 15.86 in Italy.

${ }^{3}$ Hiring and firing restrictions are typically not found to have a decisive role on overall rates of unemployment (e.g. Nickell (1998)).

${ }^{4}$ Firm flexibility in terms of "locational portfolio diversification" has been examined in the literature. More specifically, the role of cost and exchange rate uncertainty in providing a rationale for setting up plants in different countries has been respectively studied in de Meza and Van der Ploeg (1987) and in Sung and Lapan (2000).

${ }^{5}$ Cooke (1997) finds evidence that host countries' restrictive legislation governing layoffs have had a negative effect on US foreign direct investment abroad. Moran (1998, p.89) summarises evidence from investor surveys and mentions labour regulations, in particular "flexibility in hiring and laying off workers", as one of the main concerns for firm location in economies of transition and developing economies. A cursory look at available data (UNCTAD, 2001), however, does not seem to support the conventional wisdom that employment protection is unambiguously inimical to inward FDI. Amongst the European countries with higher than average values of the employment protection index constructed by Nickell, Nunziata and Quintini (2001), a significant number also show higher than average levels of inward FDI (e.g. Belgium, the Netherlands, Portugal, Sweden and Finland) - in general, no clear correlation emerges by comparing the data on shares of world FDI and employment protection levels.

${ }^{6}$ See Smith (1987), Horstmann and Markusen (1987) and (1992). For a comprehensive survey on multinationals and FDI we refer to Caves (1996).
} 
necessarily true when firms act strategically, since flexibility then implies lack of commitment power. Firms producing in locations where employment is less flexible may therefore benefit from potential advantages obtained by the commitment power that such inflexibility implies ${ }^{7}$.

We use a two-period oligopoly model, in which firms' location decisions depend on strategic and flexibility considerations. Our analysis will be driven by two substantive questions. First, do location-specific sources of inflexibility create strategic advantages that affect a country's ability to retain production of internationally mobile firms? As we argued, while this question has remained largely unexplored in the theoretical literature ${ }^{8}$, policy makers often cite strict employment protection as a threat to the anchorage of domestic industry. Second, when can we expect to find strategic clustering in the same regions and when is strategic geographical dispersion more likely? By focussing on this question, this paper complements the economic geography literature, which is mainly concerned with agglomeration formation in non-strategic set-ups 9 .

The model is outlined in Section 2. The non-strategic determinants of location are analysed in Section 3, while the strategic implications of inflexibility are discussed in Section 4. Section 5 analyses the location decisions of firms and examines the effects of increasing globalisation on the strategic incentives to geographical agglomeration. Section 6 concludes the paper.

\section{The model}

Two firms plan to launch new products, which are imperfect substitutes, to be sold in an integrated market. One firm, the Home firm, has its headquarters in the country named "Home", while the other, referred to as the Foreign firm, has its headquarters in the country named "Foreign". Each has to decide where to locate their production plant: either in "Home" or in "Foreign". We assume that the fixed costs of setting up a plant are sufficiently high to ensure that each firm chooses to have one plant only.

\footnotetext{
${ }^{7}$ The effect of adjustment costs on strategic behaviour has been discussed in set-ups without location decisions (see Lapham and Ware, 1994; Jun and Vives, 2001).

${ }^{8}$ The strategic effects of production cost differences on location choice have received ample attention in the literature (see references in footnote 6).

${ }^{9}$ See, for instance, Krugman (1991) and Fujita, Krugman and Venables (1999).
} 
Competition takes place during two periods, with firms choosing "market actions" outputs under Cournot and prices under Bertrand competition - in each period. The respective demand functions for the Home and the Foreign firm for period one are given by

$p_{1}=a-q_{1}-e q_{1}^{*}$

$p_{1}^{*}=a-q_{1}^{*}-e q_{1}$

In period two, the firms' respective demand functions are:

$p_{2}=a-q_{2}-e q_{2}^{*}+u$

$p_{2}^{*}=a-q_{2}^{*}-e q_{2}+u$

where $0 \leq e<1$ is an inverse measure of product differentiation ${ }^{10}$, and $a>0$. The Home firm's price and output are denoted by $p$ and $q$, respectively. Variables referring to the Foreign firm are starred. Subscripts 1 and 2 indicate the time period. In period one, demand for that period is observed but there is uncertainty about future demand. Hence, a stochastic component, $u$, enters the demand function for period two and is defined over the support $[\underline{u}, \bar{u}]$, with mean $E u=0$ and variance $\sigma^{2}$. The uncertainty is resolved at the start of period two ${ }^{11}$.

As mentioned above, each firm has to choose either Home or Foreign as its production location. We assume that these countries differ in one important respect. In Home, strict labour market regulations, inspired by a concern for employment protection, prevail. These cause firms to incur hiring and firing costs if, after an unexpected change in demand, they want to deviate from the period-one production (and hence employment) level. By contrast, labour market regulations in Foreign are lax, implying that expansions or reductions in production can be carried out without incurring any adjustment costs. The profit functions for the Home $(\pi)$ and the Foreign firm $\left(\pi^{*}\right)$ are respectively given by ${ }^{12}$

$\pi=R_{1}+R_{2}-C$

\footnotetext{
${ }^{10}$ Strictly speaking, the model could allow homogeneous products $(e=1)$ with Cournot behaviour, but not with Bertrand behaviour.

11 We restrict the support $[\underline{u}, \bar{u}]$ to guarantee interior solutions.

${ }^{12}$ We assume that the discount factor is unity.
} 
$\pi^{*}=R_{1}^{*}+R_{2}^{*}-C^{*}$

where $R_{t}$ denotes the Home firm's revenue in period $t$ (with $t=1,2$ ) and $C$ stands for its total cost; $R_{t}^{*}$ and $C^{*}$ refer to the Foreign firm. Total costs consist of terms that are location specific and others that are not. They depend on the location chosen by the firm and on whether it engages in FDI or not. The matrix in (4) gives the cost function for each firm in each location:

\begin{tabular}{|l|c|c|}
\cline { 2 - 3 } \multicolumn{1}{c|}{} & Home location & Foreign location \\
\hline Home firm: $\mathrm{C}$ & $c q_{1}+c q_{2}+\Lambda+\varphi$ & $c q_{1}+c q_{2}+\varphi+\delta$ \\
\hline Foreign firm: $\mathrm{C}^{*}$ & $c q_{1}^{*}+c q_{2}^{*}+\Lambda^{*}+\varphi+\delta$ & $c q_{1}^{*}+c q_{2}^{*}+\varphi$ \\
\hline
\end{tabular}

Production costs are not location specific since the marginal cost of production $(c)$ is assumed to be the same in both locations. This allows us to abstract from locationspecific cost differences. Adjustment costs $\left(\Lambda\right.$ and $\left.\Lambda^{*}\right)$ are, however, location specific; they are paid in period two, but only if the firm locates in the inflexible (Home) location. They are denoted by $\Lambda \equiv(\lambda / 2)\left(q_{2}-q_{1}\right)^{2}$ for the Home firm and by $\Lambda^{*} \equiv(\lambda / 2)\left(q_{2}^{*}-q_{1}^{*}\right)^{2}$ for the Foreign firm ${ }^{13}$. The $\lambda$-parameter $(\lambda>0)$ measures the degree of inflexibility. Firms that locate in Foreign, the flexible location, incur no adjustment costs. The firm's fixed cost of setting up a plant in its native country is denoted by $\varphi$. However, if it locates abroad, then its fixed costs are $\varphi+\delta$, with $\delta>0$. In other words, $\delta$ represents the costs associated with FDI. These may, for instance, be due to the costs incurred in dealing with foreign languages, foreign laws and a foreign taxation system ${ }^{14}$. More generally, $\delta$ can be thought of as reflecting the barriers to the mobility of capital, and will therefore shrink as the degree of market integration increases.

\footnotetext{
${ }^{13}$ This adjustment cost specification is standard in the literature. Other (e.g., linear, asymmetric) specifications would make the analysis technically more tedious without changing the qualitative results (see Hamermesh (1996, Ch.6) for a textbook survey of different employment adjustment cost specifications).

${ }^{14}$ This was first formalised by Hirsch (1976).
} 
Firms play a two-period three-stage game, acting simultaneously in each stage. The sequence of decisions is shown in figure 1. In period one, production locations, Home $(H)$ or Foreign $(F)$, are chosen (stage one). There are four possible location equilibria: two in which both firms choose the same location, $(H, H)$ and $(F, F)$, and two in which firms choose a different location, $(H, F)$ and $(F, H)$. For each location pair, the first letter refers to the Home firm's location choice, whereas the second indicates the Foreign firm's location choice. No FDI occurs in the $(H, F)$-equilibrium, while both firms engage in FDI in the $(F, H)$-equilibrium. In stage two, period-one actions are determined given demand for period one but with uncertainty about demand in period two. In period two, the uncertainty is resolved and firms choose market actions after having observed actual demand for that period (stage three).

\section{[Figure 1 about here]}

In this model, a firm's location decision is influenced both by non-strategic and strategic factors. The non-strategic aspects of the production location choice are examined first.

\section{The non-strategic dimension of the location decision}

To focus on the non-strategic location determinants, we initially abstract from strategic behaviour by considering the limit case of $e=0$ in which one firm's product is sufficiently different from its rival's that each firm effectively becomes a monopolist. In the absence of strategic behaviour, only cost and flexibility considerations will determine firms' location choices.

The location choice of a Foreign monopolist is simple: it will always choose to produce in Foreign since this choice entails maximum flexibility without incurring the cost of FDI. For a Home monopolist, the location decision involves a trade-off between the costs of FDI and the flexibility benefits associated with producing in Foreign. Due to demand uncertainty, the firm anticipates it will face adjustment costs in Home, while there will be no adjustment costs when it produces in Foreign.

Note that there is a critical level of uncertainty above which the Home monopolist will choose to produce in Foreign and below which it will choose to locate in Home. 
This critical $\sigma^{2}$-level decreases in the degree of labour market inflexibility in Home $(\lambda)$ and increases in the degree of international capital immobility $(\delta)$.

\section{Strategic implications of employment protection}

When products are substitutes, i.e. $e>0$, firms behave as duopolists and their location decisions involve both strategic and non-strategic considerations. Solving the game backwards, in this section we explore the strategic implications of employment protection at fixed locations (location choice is discussed in section 5). Since firms interact differently under Cournot and under Bertrand competition, we study the strategic implications of the production location in both forms of oligopoly. For expositional clarity, we explain the nature of the strategic effects in detail using the case in which each firm produces domestically, that is, the Home firm produces in Home and the Foreign firm in Foreign (i.e., $(H, F)$ ). The strategic behaviour in the other possible location equilibria will be discussed at the end of each subsection, using table 1 , which reports the strategic term in all possible location combinations.

\subsection{Cournot competition}

Firms' production locations affect their market actions. We first consider period two, in which locations and period-one outputs have already been chosen. Period-two reaction functions under Cournot competition are obtained by maximising period-two profits, $\pi_{2}$ and $\pi_{2}^{*}$, with respect to outputs. When each firm produces domestically, (i.e., in the $(H, F)$-case), we have $\pi_{2}=R_{2}-c q_{2}-\Lambda$ and $\pi_{2}^{*}=R_{2}^{*}-c q_{2}^{*}$. Firms' respective second-period reaction functions are given by

$$
\begin{aligned}
& q_{2}=\left(A+u-e q_{2}^{*}+\lambda q_{1}\right) /(2+\lambda) \quad \text { with } A \equiv a-c \\
& q_{2}^{*}=\left(A+u-e q_{2}\right) / 2
\end{aligned}
$$

Expressions (5a) and (5b) clearly suggest that a firm's location has implications for its flexibility. The Home firm's reaction function responds less to unexpected demand shocks than its rival's does $\left(\partial q_{2} / \partial u<\partial q_{2}^{*} / \partial u\right.$ from (5a) and (5b)). The firm in Home is also less responsive to changes in rival output $(e /(2+\lambda)<e / 2)$. In other words, the labour market inflexibility in Home affects the slope of the Home firm's 
second-period reaction function. Finally, due to adjustment costs, the Home firm's reaction function depends positively on its own past output, as captured by the term in $q_{1}$.

We now turn to stage two. Being uncertain about the demand in period two, firms simultaneously determine their outputs for period one by maximising total expected profits with respect to first-period outputs. With $\pi=\pi\left(q_{1}, q_{1}^{*}, q_{2}, q_{2}^{*}\right)$ and $\pi^{*}=\pi^{*}\left(q_{1}, q_{1}^{*}, q_{2}, q_{2}^{*}\right)$, first-order conditions are given by ${ }^{15}$

$$
\begin{aligned}
& E \pi_{q_{1}}+E\left[\pi_{q_{2}^{*}}\left(d q_{2}^{*} / d q_{1}\right)\right]=0 \\
& E \pi_{q_{1}^{*}}^{*}+E\left[\pi_{q_{2}}^{*}\left(d q_{2} / d q_{1}^{*}\right)\right]=0
\end{aligned}
$$

Subscripted variables denote partial derivatives. In (6a) and (6b), the second term on the left-hand-side captures the strategic effects. The strategic term in (6a) is positive $\left(\pi_{q_{2}^{*}}=-q_{2}<0\right.$ and $\left.d q_{2}^{*} / d q_{1}<0\right)$, implying that the firm in Home strategically overproduces in period one (or, $E \pi_{q_{1}}<0$ ). By choosing a high output level in period one, the Home firm is forced to keep its production in the next period at a relatively high level, since changing its production then is costly ${ }^{16}$. This commitment to keep production high in period two forces the rival firm to cut back its output. Meanwhile, there is no strategic behaviour by the firm in Foreign (i.e., the strategic term is zero, since, from expressions (5a) and $\left.(5 \mathrm{~b}), d q_{2} / d q_{1}^{*}=0\right)$.

Evidently, the $(H, F)$-case is not the only possible location combination that can arise. The upper half of table 1 presents the strategic terms for both firms under Cournot behaviour for all possible location combinations. If both firms engage in FDI, $(F, H)$, only the Foreign firm strategically over-produces in period one. If both firms produce in Foreign, $(F, F)$, neither firm acts strategically. Finally, if both firms produce in Home, $(H, H)$, then each firm behaves strategically and over-produces in period one.

\subsection{Bertrand competition}

\footnotetext{
${ }^{15}$ From the envelope theorem we know $\pi_{2_{q_{2}}}=\pi_{2_{q_{2}^{*}}^{*}}^{*}=0$, and thus $E \pi_{q_{2}}=E \pi_{q_{2}^{*}}^{*}=0$.

${ }^{16}$ Diagrammatically, the Home firm's expected second-period reaction function has shifted out.
} 
With Bertrand competition firms' market actions are now prices (see figure 1). Nesting the case with Bertrand competition in the model outlined in section two requires inverting the demand system given in expressions (1a)-(1b) and (2a)-(2b). Thus, we obtain

$q_{1}=\alpha-\beta\left(p_{1}-e p_{1}^{*}\right)$ and $q_{2}=\alpha-\beta\left(p_{2}-e p_{2}^{*}\right)+v$

$q_{1}^{*}=\alpha-\beta\left(p_{1}^{*}-e p_{1}\right)$ and $\quad q_{2}^{*}=\alpha-\beta\left(p_{2}^{*}-e p_{2}\right)+v$

with $\alpha \equiv a /(1+e), \beta \equiv 1 /\left(1-e^{2}\right)$ and $v \equiv u /(1+e)$.

Like under Cournot, we first concentrate on the case in which each firm produces domestically (i.e., the (H,F)-case).

Starting with the final stage of the game, the second-period price reaction functions are given by

$$
\begin{aligned}
& p_{2}=\left((1+\beta \lambda)(\alpha+v)+\beta c-\beta \lambda q_{1}\left(p_{1}, p_{1}^{*}\right)+\beta e(1+\beta \lambda) p_{2}^{*}\right) /(\beta(2+\beta \lambda)) \\
& p_{2}^{*}=\left(\alpha+v+\beta c+\beta e p_{2}\right) / 2 \beta
\end{aligned}
$$

for the Home and the Foreign firm respectively ${ }^{17}$. The Home firm's price reaction function responds more to unexpected demand shocks than its rival's does $\left(\partial p_{2} / \partial v>\partial p_{2}^{*} / \partial v\right.$ from (8a) and (8b)). Since the firm in Home is less flexible in output, unexpected demand shocks will be translated in a larger price flexibility. For the same reason, the Home firm's optimal price is more responsive to changes in its rival's price (or, $e(1+\beta \lambda) /(2+\beta \lambda)>e / 2)$. The Home firm's past output level enters negatively in its second-period price reaction function. As output is sticky in the presence of adjustment costs, a higher output in period one is associated with a higher output in period two and therefore with a lower price. This has important implications for firms' price setting in period one, to which we now turn.

\footnotetext{
17 A firm that faces adjustment costs effectively faces upwards sloping marginal costs in period two. It is well known that increasing marginal cost may lead to problems with the existence of the Bertrand equilibrium (for discussion of non-existence of equilibria under price competition, see for instance Tirole (1988), p.214). High $e$-values require low $\lambda$-values to ensure existence. We restrict attention to parameter values that ensure the existence of the four possible location equilibria.
} 
In stage two firms simultaneously set first-period prices, taking into account their effect on future prices. Total differentiation of firms' expected profits with respect to first-period prices yields the first-order conditions for period one, given by ${ }^{18}$

$$
\begin{aligned}
& E \pi_{p_{1}}+E\left[\pi_{p_{2}^{*}}\left(d p_{2}^{*} / d p_{1}\right)\right]=0 \\
& E \pi_{p_{1}^{*}}^{*}+E\left[\pi_{p_{2}}^{*}\left(d p_{2} / d p_{1}^{*}\right)\right]=0
\end{aligned}
$$

In the $(H, F)$-case, the strategic term in (9a) is positive $\left(E\left[\pi_{p_{2}^{*}}\left(d p_{2}^{*} / d p_{1}\right)\right]>0\right.$, as shown in table 1), which implies that the firm in Home strategically over-prices in period one $\left(E \pi_{p_{1}}<0\right)$. As a result, in period-one demand for the Home firm's good and hence its output will be low. It follows that, due to its production inflexibility, in period two the Home firm will keep its output low and its price high (see expression (8a)).

Unlike in the Cournot case, the firm in Foreign also has an incentive to behave strategically. More specifically, that firm strategically under-prices (i.e., since $E\left[\pi_{p_{2}}^{*}\left(d p_{2} / d p_{1}^{*}\right)\right]<0$, as reported in table $1, E \pi_{p_{2}^{*}}^{*}>0$ from $\left.(9 \mathrm{~b})\right)$. This is because it benefits from a high rival price in period two and can achieve this by cutting its price in period one. The lower Foreign price reduces the Home firm's output in period one and this raises its price in period two. Furthermore, even though it is fully flexible, the strategic effect (per unit output) for the firm in Foreign is larger in absolute value than that for the firm in Home. Both the Home firm's strategic over-pricing and the Foreign firm's strategic under-pricing in period one, guarantee that the Home firm's period-one production remains low. This will push up both firms' expected prices in the next period ${ }^{19}$.

So far, only the $(H, F)$-case has been discussed. In the $(F, H)$-case, the Home firm (now located in the flexible Foreign location) will act strategically by under-pricing in period one, while its Foreign rival (now located in Home and hence inflexible in output) will choose to over-price. If both firms produce in Foreign, $(F, F)$, neither firm has a strategic incentive. If both firms produce in Home, $(H, H)$, then both firms will

\footnotetext{
${ }^{18}$ From the envelope theorem we know $\pi_{2 p_{2}}=\pi_{2_{q 2}^{*}}^{*}=0$, and thus $E \pi_{p_{2}}=E \pi_{p_{2}^{*}}^{*}=0$.

${ }^{19}$ Diagrammatically, the strategic behaviour of both firms causes the second-period reaction function of the Home-firm to shift out.
} 
strategically under-price in period one (see table 1): even though a concern for high future prices gives each firm an incentive to keep its first-period production low (by overpricing in period one), it creates an even greater incentive for firms to keep their rival's first-period production low (by underpricing in period one $)^{20}$.

[Table 1 about here]

\section{Location patterns}

We now turn to stage one, in which firms simultaneously choose their production location. Taking the rival's production location as given, each firm simply selects the location that yields the highest expected profits. To explain how firms' location choices are determined, it will prove useful to decompose expected maximised profits $(E \pi)$ as

$$
E \pi=\pi_{0}+\int_{\underline{u}}^{\bar{u}}\left(\pi(u)-\pi_{0}\right) f(u) d u
$$

In expression (10) the first term, $\pi_{0} \equiv \pi(E u)$, denotes deterministic profits with $\pi_{0}=\theta-\Phi ; \theta$ is deterministic operating profit and $\Phi$ is the fixed costs incurred by the firm, which depends on whether the firm locates in its domestic economy $(\Phi=\varphi)$ or abroad $(\Phi=\varphi+\delta)$. The second term in (10) represents the expected profit gain from demand shocks. Because profits are convex in $u$, this term is non-negative and increasing in $\sigma^{2}$. In fact, we are able to write $\int_{\underline{u}}^{\bar{u}}\left(\pi(u)-\pi_{0}\right) f(u) d u=\gamma \sigma^{2}$, where $\gamma$ reflects the firm's ability to exploit unexpected demand shocks. Thus, expected maximised profits are $E \pi=\theta+\gamma \sigma^{2}-\Phi$. Given the costs of FDI, $\delta$, locations are determined with each firm bearing in mind deterministic operating profits, $\theta$, as well as expected profit gains from demand shocks, $\gamma \sigma^{2}$.

\footnotetext{
20 The $(\mathrm{H}, \mathrm{H})$-case refers to a situation in which both firms incur adjustment costs. Vives and Jun (1999) explore the strategic incentives for symmetric (i.e., each facing the same adjustment costs) firms, calculating Markov perfect equilibria. Their results are consistent with the results in our $(\mathrm{H}, \mathrm{H})$ case, obtained here in a two-period game. Their analysis does not include the case in which only one firm faces adjustment costs (our ( $\mathrm{H}, \mathrm{F})$ and $(\mathrm{F}, \mathrm{H})$ case) and is not concerned with firms' location choices.
} 
The value of $\gamma$ depends, among other things, on the location combination. Obviously, for both firms the ability to exploit demand shocks is higher in $(F, F)$ than in $(H, H)$. Furthermore, a firm's $\gamma$ is smallest when it is inflexible and its rival is fully flexible. Conversely, a firm's $\gamma$ is largest when it is flexible and its rival is located in the inflexible location: it then is the only firm that can fully adjust to unexpected shocks. The ranking of the $\gamma$-parameter in the different location combinations is the same under Cournot and Bertrand competition and is given by

$\gamma^{F H}>\gamma^{F F}>\gamma^{H H}>\gamma^{H F}$

for the Home firm, and by

$\gamma^{* H F}>\gamma^{* F F}>\gamma^{* H H}>\gamma^{* F H}$

for the Foreign firm, where the first superscript refers to the location of the Home firm and the second one indicates the location of the Foreign firm.

The value of $\theta$ also depends on the location combination. Note that, since the strategic interactions in Cournot competition differ from those under Bertrand behaviour, the ranking of the $\theta$-values will be different for each type of oligopoly. Under Cournot competition, the Home firm's deterministic operating profits at the different location combinations are ranked as follows

$\theta^{H F}>\theta^{F F}>\theta^{H H}>\theta^{F H}$

while the ranking for the Foreign firm is given by

$\theta^{* F H}>\theta^{* F F}>\theta^{* H H}>\theta^{* H F}$

This $\theta$-ranking is determined by the strategic behaviour of firms ${ }^{21}$. In $(H, H)$, both firms' first-period strategic overproduction (see table 1) does not yield any future output advantage, but merely results in a lower future price. Hence, deterministic operating profits are lower for both firms than in $(F, F)$, when firms do not act strategically. However, given the rival's location choice, a firm always attains higher

\footnotetext{
${ }^{21}$ In fact, this $\theta$-ranking only depends on strategic effects. Consider the hypothetical situation in which, given firms' location choices, first-period market actions are not observed. Then, in what is often called an "open-loop" equilibrium, a firm's second-period action cannot be contingent on firstperiod market actions. In this hypothetical benchmark, firms cannot act strategically and the $\boldsymbol{\theta}$-values for every location combination would be the same. For a discussion of the open-loop equilibrium, we refer to Tirole (1988, p.325-326).
} 
deterministic operating profits by committing to high output; it obtains a future gain in market share if its rival is flexible $\left(\boldsymbol{\theta}^{H F}>\boldsymbol{\theta}^{F F}\right.$ and $\left.\boldsymbol{\theta}^{* F H}>\boldsymbol{\theta}^{* F F}\right)$ and avoids a future loss in market share if its rival is inflexible $\left(\theta^{H H}>\theta^{F H}\right.$ and $\left.\theta^{* H H}>\theta^{* H F}\right)$.

Under Bertrand competition, $\theta^{F F}>\theta^{H H}$ because in $(H, H)$ both firms strategically underprice, resulting in lower prices in both periods (while there is no strategic price setting in $(F, F))$. Furthermore, we have $\theta^{H H}>\theta^{H F}$. In words, the inflexible (Home) firm's deterministic operating profits are higher if the Foreign rival is inflexible too. To understand why, first note that a firm always strategically underprices when it faces an inflexible rival. Thus, the Foreign firm will underprice both at $(H, H)$ and $(H, F)$. But, its strategic aggressiveness, which harms the Home firm, will be strongest at $(H, F)$, when it is itself flexible. Hence, under Bertrand we always have the following ranking of deterministic operating profits for the Home firm

$\theta^{F F}>\theta^{H H}>\theta^{H F}$

The position that $\theta^{F H}$ takes in this ranking depends on the level of $\lambda$. As long as the degree of employment protection $(\lambda)$ is not too high, $\theta^{F H}>\theta^{F F}$. But, as $\lambda$ increases, $\theta^{F H}$ falls and eventually, at very high $\lambda, \theta^{F H}<\theta^{H H}$. Similarly, we have the following ranking for the Foreign firm

$\theta^{* F F}>\theta^{* H H}>\theta^{* F H}$

with the position of $\theta^{* H F}$ in this ranking depending on $\lambda$ and with $\theta^{* H F}>\theta^{* F F}$ for low to moderately high levels of $\lambda$; as $\lambda$ keeps rising $\theta^{* H F}$ starts to fall and eventually we have $\theta^{* H F}<\theta^{* H H}$ at very high values for $\lambda$.

While $\theta$ and $\gamma$ depend for each form of oligopoly on the location combination (with the rankings given above), they also depend on the exogenous parameters: the degree of employment protection $(\lambda)$, the product differentiation parameter $(e)$ and the market size $(A \equiv a-c)$. Together with these parameters, firms' location choice will also depend on the FDI-cost, $\delta$, and the level of uncertainty, $\sigma^{2}$. Since the analysis of firms' location decisions involves many unwieldy algebraic expressions, graphs are used to ease the exposition. Without loss of generality, $A$ is normalised to one. The 
figures are depicted in $\left(\sigma^{2}, \lambda\right)$-space, which means that they are drawn at given values of $\delta$ and $e$.

In order to highlight the importance of $\delta$ in explaining the type of location pattern that emerges, we will distinguish between two different cases. First, we shall focus on a situation in which firms incur a significant cost of FDI (section 5.1). In that context there is a natural tendency for firms to locate domestically, thereby avoiding the high FDI-costs. We refer to the circumstances in which the Home firm produces in the inflexible Home location as "domestic anchorage". Formally, this occurs in the equilibria $(H, F)$ and $(H, H)$. The extent to which strategic behaviour affects domestic anchorage is examined in section 5.1. Second, we shall explore how increasing degrees of globalisation (in the form of falling values of $\delta$ ) influences location patterns (section 5.2). In particular, we shall investigate when strategic agglomeration - i.e., firms producing in the same location (formally, $(H, H)$ and $(F, F))$ for strategic reasons only - will emerge if firms can choose their production locations on a global level playing field.

In our analysis, we will also point out the effects of product differentiation $(e)$ on location. From section 3 we know that Cournot and Bertrand competition both converge to the monopoly case at $e=0$. As $e$ increases, the strategic effects become stronger and the two types of oligopolistic behaviour give rise to divergent location patterns. The figures are drawn for $e=0.75$, which brings out clearly the differences in location patterns between the two market structures. In contrast to the FDI-cost, the degree of product differentiation tends not to affect location patterns in a qualitatively significant way. We will briefly comment on the effects of $e$ at the end of each subsection. Hence, we cover all the qualitatively different cases that arise with different parameter combinations.

\subsection{Domestic anchorage}

Suppose that the fixed costs associated with FDI are high enough for the Foreign firm never to choose to locate in the Home country. Then, any potential strategic advantage of locating in Home would be dominated by the FDI-costs and hence the firm will, even under certainty, produce in Foreign (as uncertainty rises, the 
attractiveness of the Foreign location increases). Given that the Foreign rival produces in Foreign, we then need to examine where the Home firm will set up its plant. Figure 2 shows the location pattern that emerges in $\left(\sigma^{2}, \lambda\right)$-space. The equilibrium location combinations under Cournot and under Bertrand are indicated by superscripts $\mathrm{C}$ and $\mathrm{B}$ respectively ${ }^{22}$.

\section{[Figure 2 about here]}

Since competition is tougher under Bertrand than under Cournot behaviour, price competition makes it harder for firms to carry the costs of FDI. Based on these considerations only, one would therefore expect the area with domestic anchorage to be larger under Bertrand than under Cournot competition. In fact, it is clear from figure 2 that the opposite is true: the region in which domestic anchorage occurs is larger under Cournot (areas I and II) than under Bertrand competition (area I only). This seemingly counterintuitive result can be explained by the strategic considerations underlying firms' location decisions ${ }^{23}$. Under Bertrand competition, given rival production in Foreign, the Home firm is, from a strategic point of view, better off producing in Foreign $\left((F, F)^{B}\right.$ in area II) than in Home $\left(\theta^{F F}>\theta^{H F}\right.$, see expression (13a)). By producing in Foreign, it avoids the massive first-period price undercutting by its rival that would occur if the Home firm were to produce in Home. In contrast, under Cournot competition, the Home location holds strategic advantages $\left(\theta^{H F}>\theta^{F F}\right.$, see (12a)), implying that the Home firm will produce domestically (giving $\left.(H, F)^{C}\right)$ in area II.

As product differentiation increases (i.e. as $e$ falls), strategic behaviour is diminished. As a result, the area with domestic anchorage shrinks under Cournot competition

\footnotetext{
${ }^{22}$ In the figures, the maximum value for $\lambda$ is limited to ensure the existence of all possible equilibria. At $e=0.75, \lambda$-values smaller than (approximately) 2.5 are needed for the existence of the $(H, F)$ and $(F, H)$ equilibria under price competition (see also footnote 17 ). Under quantity competition, values for $\lambda$ do not need to be restricted. However, nothing changes qualitatively at $\lambda$-values above those depicted.

${ }^{23}$ In fact, if firms do not behave strategically in stage two, and hence $\boldsymbol{\theta}$ takes the same (open-loop) value at each location combination (see footnote 21), the area with domestic anchorage is larger under Bertrand then under Cournot competition.
} 
whereas it expands under Bertrand competition. Importantly, the area with domestic anchorage is always largest under Cournot behaviour.

\subsection{Globalisation and strategic agglomeration}

The process of globalisation implies that capital mobility increases. In our model this is captured by falling FDI-costs $(\delta)$. As barriers to capital mobility are progressively lowered, other location equilibria, beside $(H, F)$ and $(F, F)$, start to emerge. Figures 3 and 4 show the location pattern under quantity and price competition respectively. Even a brief glance at these figures confirms our previous finding that domestic anchorage remains strongest in industries with Cournot behaviour: the region in which the Home firm produces in Home is much larger under Cournot (areas Ia and $\mathrm{Ib}$ in figure 3) than under Bertrand (area I in figure 4).

With increasing globalisation, the cost of FDI $(\delta)$ falls and so it is easier for firms to invest abroad. Thus, the cost to the Home firm of acquiring flexibility by investing in Foreign is now lower. In figures 3 and 4, the threshold uncertainty locus below which the Home firm produces domestically is now lower than in figure 2. The area in which the Home firm is located in Home has shrunk (areas Ia and Ib in figure 3; area I in figure 4), meaning that domestic anchorage is less easily sustained, while FDI from the Home firm into the Foreign location becomes relatively more important. In both figures this is reflected in an enlargement of area II, in which $(F, F)$ is the unique equilibrium. Increased globalisation reduces the critical level of uncertainty above which firms produce in Foreign to obtain high production flexibility.

When low FDI costs are combined with low uncertainty, strategic considerations in the location decision become relatively more important. Under Cournot competition this strategic concern encourages inward FDI at the inflexible location (in area Ib in figure 3$)$, leading to the $(H, H)$-equilibrium. The Foreign firm actually has to jump a barrier and set up its plant in the Home location to avoid ending up in the worst possible strategic position $\left(\theta^{* H H}>\theta^{* H F}\right.$, see expression $\left.(12 \mathrm{~b})\right)$. The $(H, H)$ equilibrium is an example of strategic agglomeration, in the sense that the agglomeration would not occur in the absence of strategic behaviour. 
Under Bertrand, globalisation combined with low uncertainty can lead to FDI by the Home firm as it tries to locate in the strategically favourable flexible Foreign location (resulting in $(F, F)$ ). As shown in figure 4, provided that the level of employment protection in Home $(\lambda)$ is sufficiently high, the $(F, F)$-equilibrium occurs even at certainty $\left(\sigma^{2}=0\right)$; this too is an example of strategic agglomeration. In this case, the Home firm is willing to incur the FDI-cost purely for strategic reasons $\left(\theta^{F F}>\theta^{H F}\right.$, see expression (13a)).

\section{[Figures 3 and 4 about here]}

As globalisation deepens and $\delta$ falls further, regions in which domestic anchorage prevails become smaller still. In the limit, with complete globalisation $(\delta=0)$, firms effectively lose their nationality. The respective location patterns that then occur under quantity and under price competition are shown in figures 5 and 6 . Even then, firms may want to locate in the inflexible Home location. In fact, at sufficiently low levels of uncertainty, $(H, H)$ is the unique equilibrium under Cournot competition. Moreover, $(H, H)$ can also be an equilibrium (together with $(F, F)$ ) under Bertrand competition, but only at very high degrees of employment protection. This $(H, H)$ equilibrium is also an example of strategic agglomeration because, at high $\lambda$, $\theta^{* H H}>\theta^{* H F}$; given that the Home firm produces in Home, the Foreign firm sets up production in Home too, thus avoiding an unfavourable strategic position.

\section{[Figures 5 and 6 about here]}

The location effects of deepening globalisation prove to be relatively robust to changing degrees of product differentiation. It is worth mentioning that as product differentiation increases (e falls), strategic agglomeration still occurs, but only at lower levels of uncertainty.

\section{Conclusions}


We have explored how differences in labour market flexibility affect location decisions when future demand is uncertain and firms act strategically. When demand uncertainty is very high, firms will cluster in countries where the labour market is relatively flexible, thus avoiding costly redundancy packages during economic slowdowns and expensive overtime payments or hiring costs in economic booms. Among countries with a high degree of capital mobility, this location pattern may even prevail at relatively low levels of uncertainty.

However, when firms act strategically, they may be willing to forego flexibility and produce in countries where the labour market is relatively inflexible in order to obtain strategic advantages. This is the case when the firms engage in Cournot behaviour. Under quantity competition an inflexible location allows a firm to commit to high future output, which makes the inflexible location more attractive at low levels of uncertainty. This strategic advantage helps to maintain domestic anchorage of firms in locations with strict labour regulations. Under price competition however, a firm located in the inflexible country faces aggressive pricing from its flexible rival in period one. As a result, the inflexible location is unfavourable both from a strategic and a flexibility perspective. Hence, both strategic and flexibility incentives work against domestic anchorage under Bertrand competition.

We have shown that deepening globalisation can lead to a greater tendency for the development of strategic agglomeration. This is the case under both Cournot and Bertrand competition. Under Cournot competition, firms facing low FDI-costs cluster in the inflexible location when uncertainty is low (this can also occur under Bertrand competition at very high levels of employment protection and when uncertainty is very low). Such clustering has however a prisoner's dilemma character with firms all producing higher output and enjoying less flexibility than they would in a location with lower labour adjustment costs. Under Bertrand competition, when strategic agglomeration occurs, it does so mainly in the flexible location as firms flee the strategically unfavourable inflexible location.

When formulating the policy lessons from this analysis, one should proceed with caution. Throughout this paper, we have assumed that the level of employment protection is exogenous. This is a reasonable assumption since the political unwillingness to change employment protection regulations, once these are in place, 
is often strong. It does not, however, preclude policy makers from using locationdependent fiscal incentives to increase the attractiveness of their region. Our analysis suggests that countries with strict labour regulations will find it less difficult to achieve domestic anchorage of key industries, by using fiscal incentives, when firm behaviour is approximated by Cournot rather than by Bertrand competition ${ }^{24}$.

Finally, we have not derived optimal employment protection levels in this paper. This would require taking into account the link that typically exists between employment protection and labour costs: employment protection tends to push up labour cost - not least because it strengthens workers' bargaining power - which would in turn affect a location's attractiveness for investors. Whether and how a government should design its labour standards optimally in order to achieve domestic anchorage and to maximise its FDI-inflow is a question left for future research.

\footnotetext{
${ }^{24}$ Whether firms' behaviour is better described by Cournot or by Bertrand competition would need to be empirically investigated on an industry-by-industry basis. There exists a substantial empirical literature on this issue (for a textbook survey, see Martin (2002), Ch.7).
} 


\section{References}

Bentolila, S. and G. Bertola (1990), "Firing costs and labor demand: How bad is Eurosclerosis", Review of Economic Studies, 57, 381-402.

Caves, R.E. (1996), Multinational Enterprise and Economic Analysis, $2^{\text {nd }}$ ed., Cambridge University Press, Cambridge.

Cooke, W. N. (1997), "The influence of industrial relations factors on U.S. foreign direct investment abroad", Industrial and Labor Relations Review, 51, 3-17.

de Meza, D. and F. Van der Ploeg (1987), "Production flexibility as a motive for multinationality", The Journal of Industrial Economics, 35, 343-351.

Fujita, M., P. Krugman and A. Venables (1999), The spatial economy: Cities, regions and international trade, Cambridge and London: MIT Press.

Hamermesh, D. (1996), Labor Demand, Princeton: Princeton University Press.

Hirsch, S. (1976), "An international trade and investment theory of the firm", Oxford Economic Papers, 28, 258-269.

Horstmann, I. And J. Markusen (1987), "Strategic investments and the development of multinationals", International Economic Review, 28, 109-121.

Horstmann, I. And J. Markusen (1992), "Endogenous market structures in international trade (natura facit saltum)", Journal of International Economics, $32,109-129$.

Jun, B. and X. Vives (2001), Incentives in dynamic duopoly, Centre for Economic Policy Research, Discussion Paper 2899.

Krugman, P. (1991), Geography and trade, Cambridge and London: MIT Press.

Lapham, B. and R. Ware (1994), "Markov puppy dogs and related animals", International Journal of Industrial Organization, 12, 569-593.

Layard, R., S. Nickell and R. Jackman (1991), Unemployment, Oxford: Oxford University Press.

Lazear, E. (1990), "Job security provisions and employment", The Quarterly Journal of Economics, 699-726.

Lindbeck, A. and D. Snower (1988), "Job security, work incentives and unemployment", Scandinavian Journal of Economics, 90, 453-474.

Martin, S. (2002), Advanced Industrial Economics, second ed., Oxford: Blackwell Publishers.

Moran, T. (1998), Foreign direct investment and development, Institute for International Economics, Washington, DC.

Nickell, S. (1998), "Unemployment: Questions and some answers", Economic Journal, 108, 802-816.

Nickell, S., L. Nunziata and G. Quintini (2001), "The Beveridge curve, unemployment and wages in the OECD from the 1960s to the 1990s", mimeo, London School of Economics.

Smith, A. (1987), "Strategic investment, multinational corporations and trade policy", European Economic Review, 31, 89-96.

Sung, H. and H. Lapan (2000), "Strategic foreign direct investment and exchange-rate uncertainty", International Economic Review, 41, 411-423.

Tirole, J. (1988), The Theory of Industrial Organisation, Cambridge, Massachusetts: The MIT Press.

UNCTAD (2001), World Investment Report, United Nations, New York and Geneva. 
Figure 1: The sequence of decisions

Stage 1: $\quad$ Firms choose location

Possible combinations:

$(\mathrm{F}, \mathrm{F}) ;(\mathrm{H}, \mathrm{F}) ;(\mathrm{F}, \mathrm{H}) ;(\mathrm{H}, \mathrm{H})$

Stage 2: $\quad$ Firms choose $1^{\text {st }}$-period market actions:

- $\left(q_{1}, q^{*}{ }_{1}\right)$ if Cournot competition

$\bullet\left(\mathrm{p}_{1}, \mathrm{p}_{1}^{*}\right)$ if Bertrand competition

\section{PERIOD 1}

Uncertainty

Stage 3: $\quad$ Firms choose $2^{\text {nd }}-$ period market actions:

- $\left(q_{2}, q^{*}{ }_{2}\right)$ if Cournot competition

PERIOD 2

\section{Certainty}

- $\left(\mathrm{p}_{2}, \mathrm{p}_{2}^{*}\right)$ if Bertrand competition

Table 1: The strategic terms in all possible location combinations

\begin{tabular}{|l|c|c|c|c|c|}
\hline & $\begin{array}{c}\text { Strategic } \\
\text { term }\end{array}$ & $(\boldsymbol{H}, \boldsymbol{H})$ & $(\boldsymbol{H}, \boldsymbol{F})$ & $(\boldsymbol{F}, \boldsymbol{H})$ & $(\boldsymbol{F}, \boldsymbol{F})$ \\
\hline Home firm & $E \pi_{q_{2}} \frac{d q_{2}^{*}}{d q_{1}}$ & $\frac{e^{2} \lambda}{\Delta^{H H}} E q_{2}^{H H}$ & $\frac{e^{2} \lambda}{\Delta^{H F}} E q_{2}^{H F}$ & 0 & 0 \\
\hline Foreign firm & $E \pi_{q_{2}}^{*} \frac{d q_{2}}{d q_{1}^{*}}$ & $\frac{e^{2} \lambda}{\Delta^{H H}} E q_{2}^{* H H}$ & 0 & $\frac{e^{2} \lambda}{\Delta^{F H}} E q_{2}^{* F H}$ & 0 \\
\hline Home firm & $E \pi_{p_{2}^{*}} \frac{d p_{2}^{*}}{d p_{1}}$ & $-\frac{e^{2} \beta \lambda}{\nabla^{H H}} E q_{2}^{H H}$ & $\frac{e^{2} \beta \lambda}{\nabla^{H F}} E q_{2}^{H F}$ & $-2 \frac{e^{2} \beta \lambda}{\nabla^{F H}} E q_{2}^{F H}$ & 0 \\
\hline Foreign firm & $E \pi_{p_{2}}^{*} \frac{d p_{2}}{d p_{1}^{*}}$ & $-\frac{e^{2} \beta \lambda}{\nabla^{H H}} E q_{2}^{* H H}$ & $-2 \frac{e^{2} \beta \lambda}{\nabla^{H F}} E q_{2}^{* H F}$ & $\frac{e^{2} \beta \lambda}{\nabla^{F H}} E q_{2}^{*{ }^{*} H}$ & 0 \\
\hline
\end{tabular}

Note: $\Delta^{H H} \equiv(2+\lambda)^{2}-e^{2}>0 ; \Delta^{H F}=\Delta^{F H} \equiv 2(2+\lambda)-e^{2}>0$

$$
\nabla^{H H} \equiv(2+\beta \lambda)^{2}-e^{2}(1+\beta \lambda)^{2}>0 ; \nabla^{H F}=\nabla^{F H} \equiv 2(2+\beta \lambda)-e^{2}(1+\beta \lambda)>0
$$


Figure 2: The location pattern under Cournot and Bertrand competition: High FDI-costs $(\delta=0.01 ; e=0.75 ; A=1)$

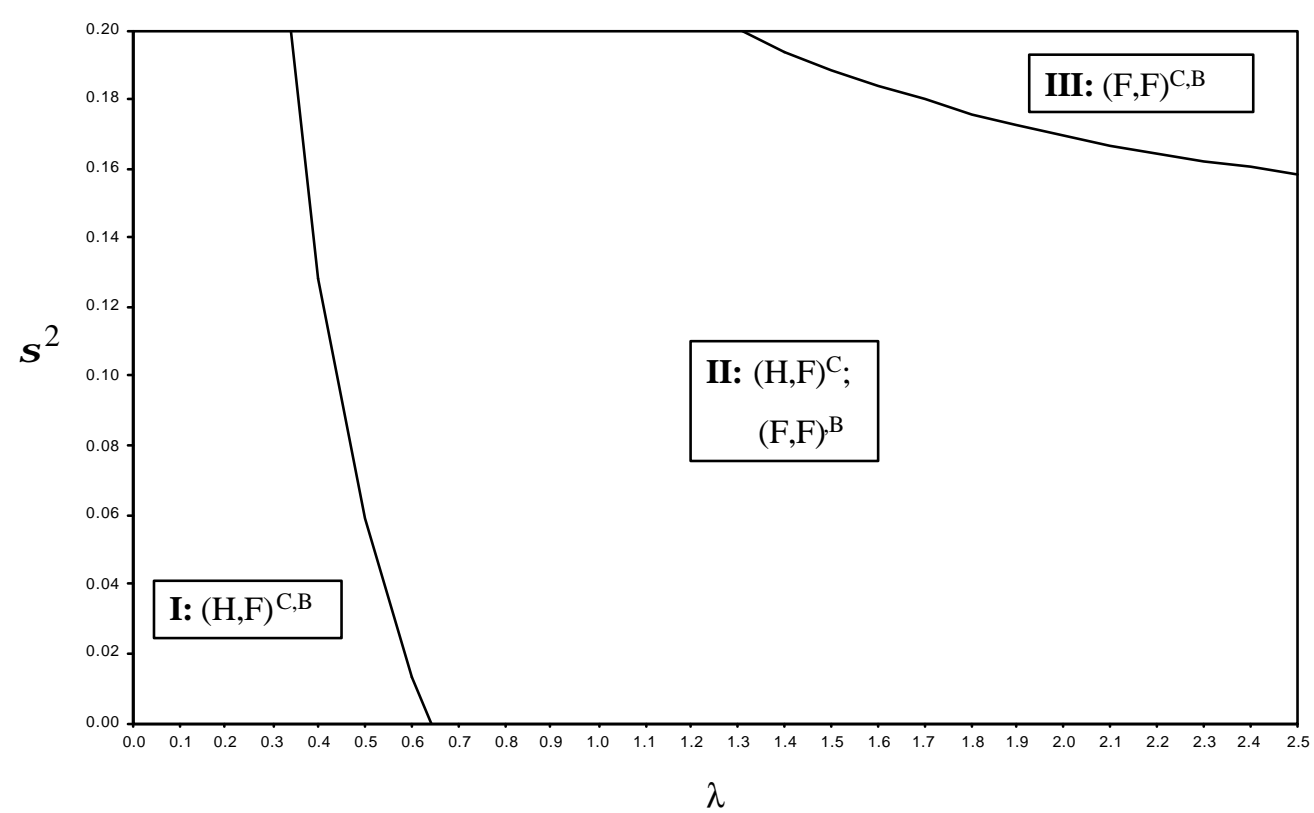


Figure 3: The location pattern under Cournot competition with increased globalisation: Intermediate FDI-costs $(\delta=0.005 ; e=0.75 ; A=1)$

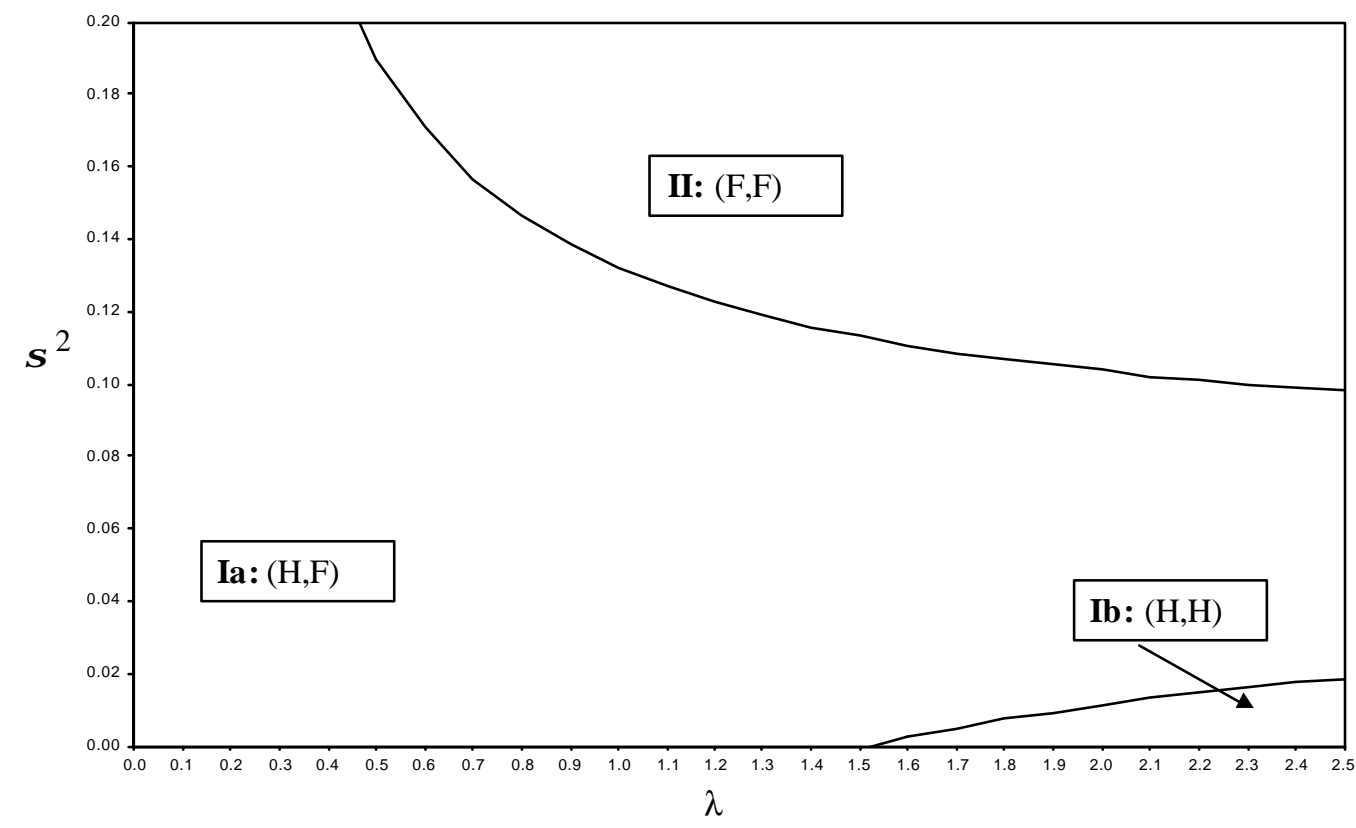

Figure 4: The location pattern under Bertrand competition with increased globalisation: Intermediate FDI-costs $(\delta=0.005 ; e=0.75 ; A=1)$

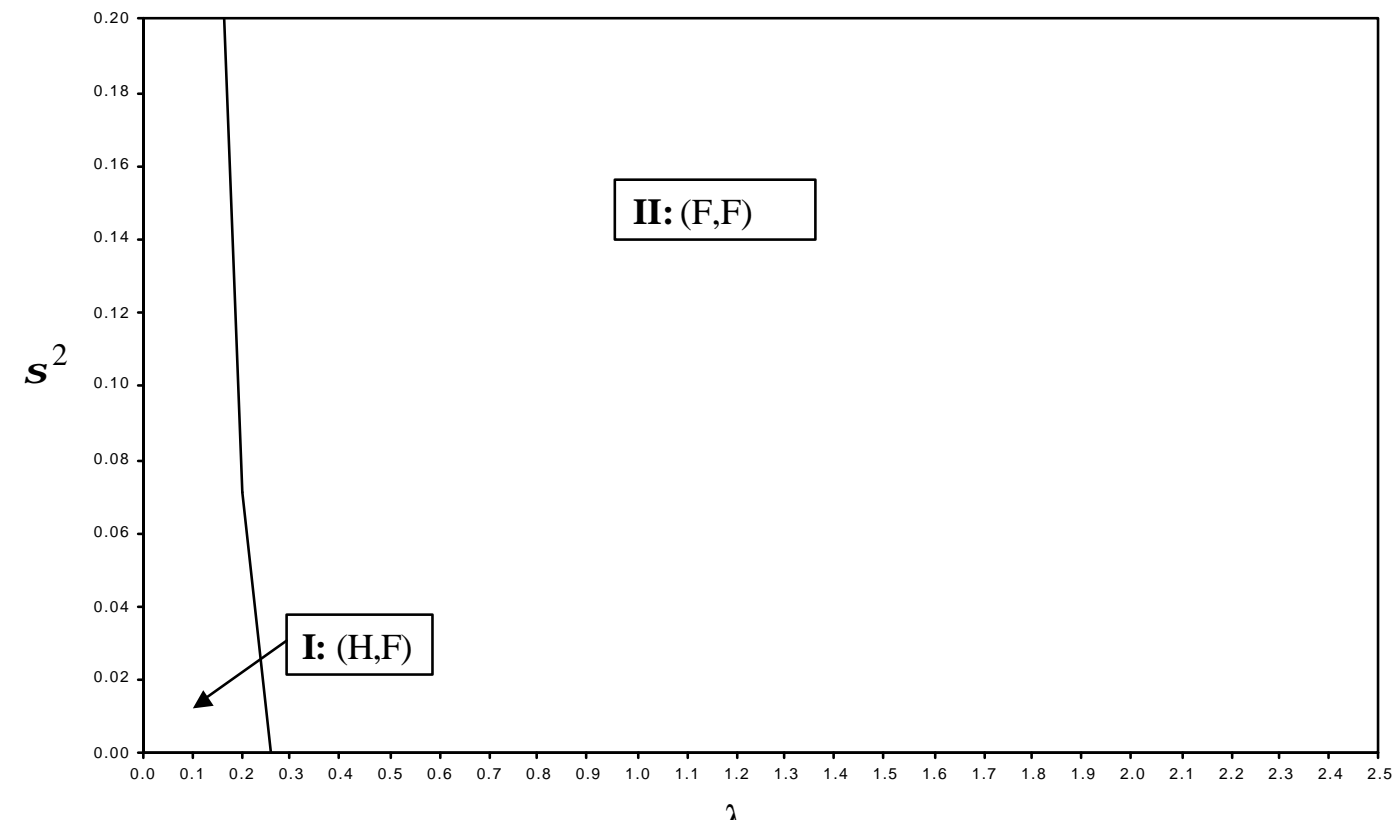


Figure 5: The location pattern under Cournot competition with complete globalisation: No FDI-costs $(\delta=0 ; e=0.75 ; A=1)$

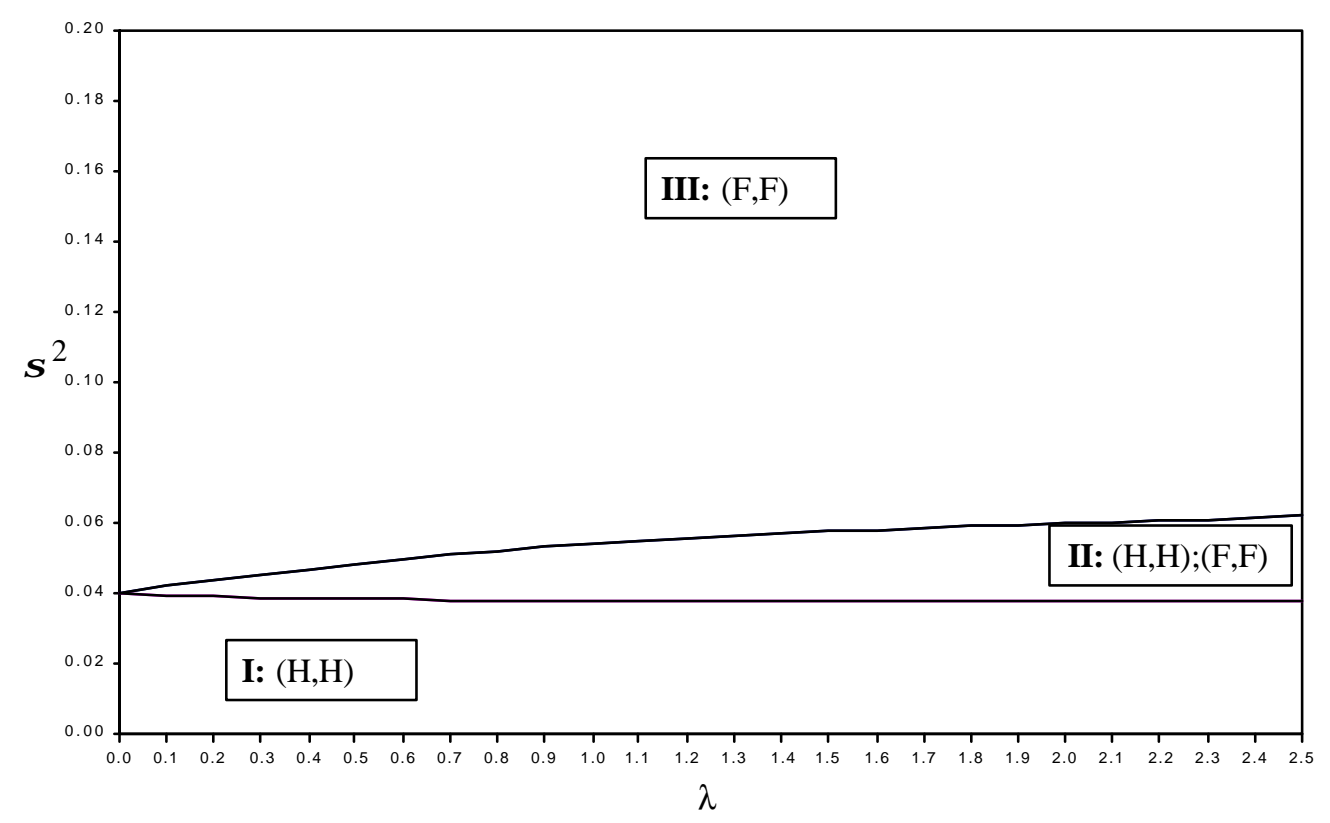

Figure 6: The location pattern under Bertrand competition with complete globalisation: No FDI-costs $(\delta=0 ; e=0.75 ; A=1)$

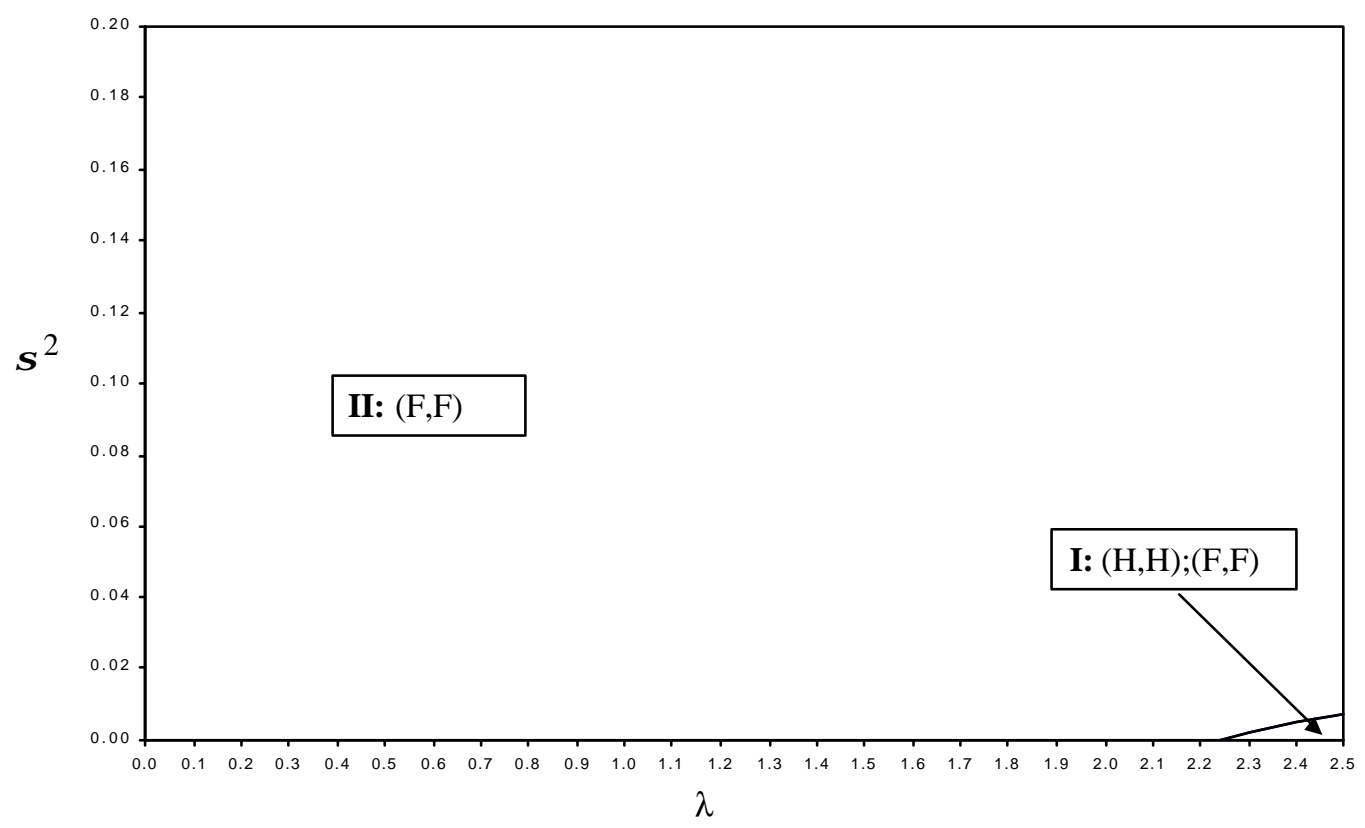

